\title{
Review Article Novel Strategies for the Treatment of Chondrosarcomas:
Targeting Integrins
}

\author{
Jui-Chieh Chen, ${ }^{1,2}$ Yi-Chin Fong, ${ }^{3,4}$ and Chih-Hsin Tang ${ }^{1,5,6}$ \\ ${ }^{1}$ Graduate Institute of Basic Medical Science, China Medical University, No. 91, Hsueh-Shih Road, Taichung 40402, Taiwan \\ ${ }^{2}$ National Institute of Cancer Research, National Health Research Institutes, Miaoli 35053, Taiwan \\ ${ }^{3}$ School of Chinese Medicine, College of Chinese Medicine, China Medical University, Taichung 40402, Taiwan \\ ${ }^{4}$ Department of Orthopedic Surgery, China Medical University Hospital, Taichung 40402, Taiwan \\ ${ }^{5}$ Department of Pharmacology, School of Medicine, China Medical University, Taichung 40402, Taiwan \\ ${ }^{6}$ Department of Biotechnology, College of Health Science, Asia University, Taichung 41354, Taiwan
}

Correspondence should be addressed to Chih-Hsin Tang; chtang@mail.cmu.edu.tw

Received 29 October 2013; Accepted 9 December 2013

Academic Editor: Po-Lin Kuo

Copyright (C) 2013 Jui-Chieh Chen et al. This is an open access article distributed under the Creative Commons Attribution License, which permits unrestricted use, distribution, and reproduction in any medium, provided the original work is properly cited.

\begin{abstract}
Chondrosarcomas are a heterogeneous group of malignant bone tumors that are characterized by the production of cartilaginous extracellular matrix. They are the second most frequently occurring type of bone malignancy. Surgical resection remains the primary mode of treatment for chondrosarcomas, since conventional chemotherapy and radiotherapy are largely ineffective. Treatment of patients with high-grade chondrosarcomas is particularly challenging, owing to the lack of effective adjuvant therapies. Integrins are cell surface adhesion molecules that regulate a variety of cellular functions. They have been implicated in the initiation, progression, and metastasis of solid tumors. Deregulation of integrin expression and/or signaling has been identified in many chondrosarcomas. Therefore, the development of new drugs that can selectively target regulators of integrin gene expression and ligand-integrin signaling might hold great promise for the treatment of these cancers. In this review, we provide an overview of the current understanding of how growth factors, chemokines/cytokines, and other inflammation-related molecules can control the expression of specific integrins to promote cell migration. We also review the roles of specific subtypes of integrins and their signaling mechanisms, and discuss how these might be involved in tumor growth and metastasis. Finally, novel therapeutic strategies for targeting these molecules will be discussed.
\end{abstract}

\section{Chondrosarcomas}

Chondrosarcomas are a heterogeneous group of malignant bone tumors with diverse histopathology and clinical behavior, which are characterized by the production of cartilage matrix. They are the second most common type of skeletal malignancy after osteosarcomas [1]. Chondrosarcomas are usually found within flat bones; the pelvis and femur are two common sites of involvement, although any bone may be affected $[2,3]$. These malignant cartilaginous tumors may either arise de novo or develop from pre-existing benign lesion (e.g., enchondromas and osteochondromas), termed primary (or conventional), and secondary chondrosarcomas, respectively. Tumors can arise in both skeletal (central) and extraskeletal (peripheral) locations [4]. The majority of cases are primary central chondrosarcomas; together, primary central and secondary peripheral chondrosarcomas constitute approximately $85 \%$ of all chondrosarcomas. Other specialized types of chondrosarcoma, such as dedifferentiated, clear cell, and mesenchymal chondrosarcomas, account for the remaining $10 \%-15 \%$ of cases $[3,5]$.

Chondrosarcomas are classified into three histological grades (grades 1-3), based on the extent of cellularity, nuclear atypia, nuclear staining (hyperchromasia), mucomyxoid matrix changes, and increased vascularization [69]. Approximately $90 \%$ of conventional chondrosarcomas are grade 1 or 2, which have an indolent clinical course, low metastatic potential, and good prognosis; the remaining 5-10\% are grade 3 tumors, which have high metastatic potential and are associated with poor outcomes $[3,10,11]$. 
For chondrosarcomas, prognosis is strongly correlated with histological grade, as well as with the adequacy of the resection margins [12,13]. Low-grade chondrosarcomas show little cellularity and an abundant matrix that resembles hyaline cartilage. These tumors rarely metastasize and are therefore often managed with intralesional curettage and resection. In contrast, high-grade conventional chondrosarcomas are highly cellular, with little or no cartilaginous matrix. Highgrade tumors often metastasize, leading to lethality in most cases; for these, radical excision margins, or even amputation, may be recommended [3].

Chemotherapy and radiotherapy are largely ineffective for treating chondrosarcomas, due to the slow growth, abundant extracellular matrix (ECM), low percentage of dividing cells, and poor vascularity of these tumors [14-17]. Moreover, some studies indicate that chondrosarcoma cells can express multidrug-resistance gene products, such as P-glycoprotein, thereby reducing the absorption of drugs, and giving rise to chemotherapy resistance $[18,19]$. Surgical resection remains the primary mode of treatment for chondrosarcomas. In a minority of patients, local recurrence or metastasis occurs, and can result in death; this is more prevalent in those with high-grade tumors $[3,16]$. The above features make the clinical management of chondrosarcomas particularly challenging, and new therapeutic strategies are urgently needed. One type of approach focuses on inhibiting the processes of metastasis and invasion, and may facilitate the development of effective adjuvant therapy. Integrins have been considered potential therapeutic targets because they are exposed on the cell surface and are sensitive to pharmacological blockade.

\section{Characteristics of Integrins}

Integrins are a family of heterodimeric transmembrane glycoproteins that are found on nearly all cells, where they function as adhesion receptors, mediating dynamic cell-cell and cellextracellular matrix interactions. Through these interactions, integrins play critical roles in cancer cell migration, invasion, and metastasis-processes that contribute to tumor progression [20]. To date, at least 24 unique integrin heterodimers have been identified. These heterodimers are formed from various combinations of $18 \alpha$-subunits and $8 \beta$-subunits, which interact noncovalently. Each integrin subunit consists of a large extracellular domain, a single type I transmembrane domain, and a short intracellular cytoplasmic tail domain [21]. The ligand-binding site of an integrin heterodimer lies at the interface between the two subunits. Their cytoplasmic domains form connections with the cytoskeleton, enabling integrins to serve as a link between the ECM and the cytoskeleton.

Ligand specificity is determined by the extracellular domain of the integrins. Five main groups have been identified: arginine-glycine-aspartate (RGD)-binding, the $\alpha 4$ family, laminin-binding, I-domain collagen-binding, and leukocyte adhesion integrins. Approximately one third of integrins have binding sites for the RGD sequence, which is found on many ECM proteins. Although the RGD sequences within collagen and laminin are not normally exposed, denaturation or cleavage of these proteins may result in exposure of the RGD sequence and subsequent integrin binding. Generally, $\alpha 4$ integrins recognize the leucineaspartic acid-valine (LDV) tripeptide, collagen-binding integrins recognize a triple helical collagen peptide containing the glycine-phenylalanine-hydroxyproline-glycineglutamate-arginine (GFOGER) motif [22, 23]. Integrins do not simply act as adhesion molecules; they can also function as bidirectional signaling molecules, controlling a variety of cell functions such as proliferation, differentiation, survival/apoptosis, cell shape, polarity, or motility, as well as gene expression [21].

\section{Integrin-Dependent Signaling}

Although integrins lack intrinsic kinase activity, signal transduction can be induced by the assembly of signaling complexes on the cytoplasmic domains of integrin subunits. Through interactions of their cytoplasmic domains with a wide variety of adaptor proteins, integrins are able to deliver signals into the cell in response to extracellular cues ("outsidein" signaling). In addition, some cytoplasmic interactions can induce conformational changes in integrin molecules. This can affect their activation state by modulating their binding affinity for extracellular ligands ("inside-out" signaling) [2426]. In the inactive or low-affinity state, integrins are in a "bent" conformation, with the transmembrane and cytoplasmic domains close together; this impedes ligand engagement and maintains the low-affinity state. The binding of talins and kindlins to their respective binding regions of the $\beta$ integrin cytoplasmic tails induces conversion from the bent to the extended conformation. This separates the cytoplasmic and transmembrane subunits and results in a shift to the activated or high-affinity state. When activated integrins bind to ligands, they cluster at the plasma membrane. This clustering promotes intracellular signaling, resulting in the formation of tight focal adhesions, actin cytoskeletal assembly, and activation of multiple downstream signaling pathways that influence a variety of cellular functions [27-29]. Precise regulation of ligand binding affinity is therefore critical for proper integrin function.

The canonical view has been that ECM ligands bind to their cognate integrins and initiate signaling via specific pathways, to give rise to distinct cell responses. However, accumulating evidence reveals that several integrins are able to crosstalk with oncogenic signal transducers, such as ErbB, Ras, and Src, to promote tumorigenesis [30-34]. Cooperative signaling between integrins, growth factor receptors, and cytokine receptors has also been implicated in tumor progression [35-41]. Upon ligand binding, integrins may trigger cells to secrete growth factors and/or cytokines, which in turn can bind to their receptors in an autocrine or paracrine manner to induce further signaling. For example, the activation of integrin $\alpha \mathrm{v} \beta 3$ can trigger phosphorylation of p66 Shc; this has been shown to upregulate the expression of vascular endothelial growth factor (VEGF), leading to tumor growth and angiogenesis in human prostate and breast cancer cells 
[38]. In pancreatic cancer cells, the $\alpha 6 \beta 1$ and $\alpha 3 \beta 1$ integrins interact with laminin-1 to mediate cell migration; this process involves the upregulation of CXC chemokine receptor 4 (CXCR4) and IL-8 expression in response to the chemokine ligand CXCL12, also known as stromal cell-derived factor-1 (SDF-1) [42]. Integrin activation of growth factor receptors, through collaborative mechanisms, has also been reported to induce downstream signaling [43]. Alternatively, both growth factor and chemokine signaling may regulate integrin function by directly controlling integrin expression levels.

\section{Regulation of Integrin Gene Expression}

A number of growth factors and chemokines/cytokines have been found to regulate the expression of integrins in many malignancies, indicating a critical role in cancer progression. For example, heparin-binding EGF-like growth factor has been observed to increase integrin expression in human breast and esophageal cancer cells $[67,68]$. Binding of the CXCL12 chemokine to its receptor (CXCR4) may regulate tumor dissemination in prostate tumor cells by enhancing expression of $\alpha \mathrm{v} \beta 3$ integrins [40]. More recently, a study demonstrated that CXCL12 strongly induced $\alpha \mathrm{v} \beta 6$ integrin expression in ovarian cancer, leading to enhanced urokinase plasminogen activator (uPA)-mediated ECM degradation and cell invasion [69]. In human osteosarcoma cells, the CCL5/CCR5 axis can induce increased expression of $\alpha \mathrm{v} \beta 3$ integrin via the MEK, ERK, and NF- $\kappa \mathrm{B}$ pathways, thereby contributing to cell migration [70]. The pro-inflammatory cytokine interleukin-1 $\alpha$ (IL-1 $\alpha$ ) can induce selective upregulation of $\alpha 6 \beta 1$ integrin in pancreatic cancer cells and has been suggested to modulate tumor aggressiveness [71, 72]. Transforming growth factor- $\beta 1$ (TGF- $\beta 1$ ), a multifunctional cytokine, can promote human hepatocellular carcinoma (HCC) cell invasion by stimulating $\alpha 3$ integrin expression [44]. Another study found that TGF- $\beta 1$ treatment promotes gastric carcinoma cell adherence by increasing $\alpha 3$ integrin levels [67].

In human chondrosarcoma cells, numerous studies have shown that growth factors, chemokines/cytokines, and other inflammation-related molecules can control the expression of specific integrins to promote cell migration. Among the growth factors, insulin-like growth factor-I (IGF-I) is able to enhance the migration of chondrosarcoma cells by increasing $\alpha \mathrm{v} \beta 1$ integrin expression, through the IGFI receptor/PI3K/Akt/NF- $\kappa$ B pathway [45]. Brain-derived neurotrophic factor (BDNF) is a small protein from the neurotrophin family of growth factors whose expression has been associated with disease status and outcomes in various cancers. Recent research has shown that BDNF enhances the migration of chondrosarcoma by increasing $\beta 5$ integrin expression, through the TrkB receptor, $\mathrm{PI} 3 \mathrm{~K}, \mathrm{Akt}$, and NF- $\kappa \mathrm{B}$ pathways [46] (Table 1).

Interleukin-8 (IL-8), a chemokine also known as CXCL8, interacts with the CXCR1 and CXCR2 receptors to activate PI3K and Akt pathways, and induce AP-1 activation. In human chondrosarcoma cells, IL-8 induced upregulation of $\alpha \mathrm{v} \beta 3$ integrin expression and increased cell migration [47]. Metastasis, particularly to the lungs, is often observed with high-grade chondrosarcomas. Interestingly, the CXCL12/SDF-1 chemokine, which is constitutively secreted by human lung epithelium cells, has been shown to enhance the invasiveness of chondrosarcoma cells by increasing $\alpha v \beta 3$ integrin expression, through the CXCR4/ERK/NF$\kappa \mathrm{B}$ pathway. It has also been observed that the expression of CXCR4 in human chondrosarcoma tissues and chondrosarcoma cell lines is higher than in normal cartilage and in human chondrocytes. This could potentially account for the homing of chondrosarcoma cells to the lung [48] (Table 1).

Accumulating evidence suggests that fat tissue can function as an endocrine organ, producing and secreting a variety of bioactive substances that are referred to as adipocytokines or adipokines. Most adipocytokines are pro-inflammatory cytokines, such as tumor necrosis factor- $\alpha$ (TNF- $\alpha$ ). Various adipocytokines, including TNF- $\alpha$, leptin, and adiponectin, have been reported to enhance chondrosarcoma cell migration by increasing the expression of specific integrins. A range of signaling pathways are involved. For example, TNF$\alpha$ and leptin were found to increase $\alpha \mathrm{v} \beta 3$ integrin expression, through their effects on the MEK/ERK/IKK $\alpha / \beta / \mathrm{NF}-\kappa \mathrm{B}$ and the OBR1/IRS-1/PI3K/Akt/NF- $\kappa$ B pathways, respectively $[49,50]$. Adiponectin is a member of the $\mathrm{Clq}$ and tumor necrosis factor superfamily, and structurally resembles TNF$\alpha$. Adiponectin can promote migration of human chondrosarcoma cells by upregulating $\alpha 2 \beta 1$ integrin, via AdipoR-, AMPK-, p38-, IKK $\alpha / \beta-$, and NF- $\kappa \mathrm{B}$-dependent pathways [51]. Macrophage migration-inhibitory factor (MIF), a proinflammatory cytokine involved in macrophage migration and activation, is able to enhance the migration of chondrosarcoma cells by increasing $\alpha \mathrm{v} \beta 3$ integrin expression, mediated via PI3K/Akt/NF- $\kappa$ B signaling [52] (Table 1).

The transforming growth factor- $\beta$ (TGF- $\beta$ ) superfamily includes the prototypical member TGF- $\beta$, and numerous others, such as bone morphogenetic proteins (BMPs) and glial cell derived neurotrophic factor (GDNF). Many of these proteins are known to play pivotal roles in tumor progression, invasion, and metastasis. TGF- $\beta$ has been previously shown to increase cell motility and $\alpha \mathrm{v} \beta 3$ integrin expression in human chondrosarcoma cells, via pathways involving PI3K, Akt, and NF- $\kappa$ B [53]. BMPs are proteins originally isolated from bone tissue, and are capable of ectopically inducing new cartilage and bone formation. BMP- 2 has been found to act through PI3K/Akt, IKK $\alpha / \beta$, and NF- $\kappa \mathrm{B}$, resulting in increased $\beta 1$ integrin expression and migration of human chondrosarcoma cells [54]. GDNF is a factor required for survival, proliferation, and activation of glioma cells. GDNF has been shown to promote the migration of human chondrosarcoma cells by upregulating $\alpha \mathrm{v} \beta 3$ integrin expression, through activation of the MEK/ERK, IKK $\alpha / \beta$, and NF$\kappa \mathrm{B}$ pathways [55]. A novel cytokine system, consisting of receptor activator of NF- $\kappa \mathrm{B}$ ligand (RANKL), its receptor, RANK, and the protein osteoprotegerin (OPG), has been identified and extensively characterized for its role in bone remodeling. The RANKL/RANK signaling axis has also been found to regulate cell migration in human chondrosarcoma cells, through MEK, ERK, IKK $\alpha / \beta$, and NF- $\kappa \mathrm{B}$ signaling and upregulation of $\beta 1$ integrin [56] (Table 1). 
TABLE 1: Regulation of integrin expression in human chondrosarcoma cells.

\begin{tabular}{|c|c|c|c|c|}
\hline Groups & Activators & Integrins & Pathway & References \\
\hline \multirow{2}{*}{ Growth factors } & Insulin-like growth factor-I (IGF-I) & $\alpha 5 \beta 1$ & IGF-I receptor/PI3K/Akt/NF- $\kappa \mathrm{B}$ & {$[44]$} \\
\hline & $\begin{array}{l}\text { Brain derived neurotrophic factor } \\
\text { (BDNF) }\end{array}$ & $\beta 5$ & TrkB receptor/PI3K/Akt/NF- $\kappa \mathrm{B}$ & {$[45]$} \\
\hline \multirow{2}{*}{ Chemokines } & IL-8/CXCL8 & $\alpha \mathrm{v} \beta 3$ & CXCR1 and CXCR2/PI3K/Akt/AP-1 & [46] \\
\hline & CXCL12/SDF-1 & $\alpha \mathrm{v} \beta 3$ & CXCR4/ERK/NF- $\kappa \mathrm{B}$ & [47] \\
\hline \multirow{4}{*}{$\begin{array}{l}\text { Pro-inflammatory } \\
\text { cytokines }\end{array}$} & TNF- $\alpha$ & $\alpha \mathrm{v} \beta 3$ & MEK/ERK/IKK $\alpha / \beta / \mathrm{NF}-\kappa \mathrm{B}$ & [48] \\
\hline & Leptin & $\alpha \mathrm{v} \beta 3$ & OBR1/IRS-1/PI3K/Akt/NF- $\kappa$ B & {$[49]$} \\
\hline & Adiponectin & $\alpha 2 \beta 1$ & AdipoR/AMPK/p38/IKK $\alpha / \beta / N F-\kappa B$ & {$[50]$} \\
\hline & $\begin{array}{l}\text { Macrophage migration-inhibitory factor } \\
\text { (MIF) }\end{array}$ & $\alpha \mathrm{v} \beta 3$ & $\mathrm{PI} 3 \mathrm{~K} / \mathrm{Akt} / \mathrm{NF}-\kappa \mathrm{B}$ & {$[51]$} \\
\hline \multirow{4}{*}{ Cytokines } & TGF- $\beta$ & $\alpha \mathrm{v} \beta 3$ & $\mathrm{PI} 3 \mathrm{~K} / \mathrm{Akt} / \mathrm{NF}-\kappa \mathrm{B}$ & {$[52]$} \\
\hline & Bone morphogenetic proteins (BMPs) & $\beta 1$ & $\mathrm{PI} 3 \mathrm{~K} / \mathrm{Akt} / \mathrm{IKK} \alpha / \beta / \mathrm{NF}-\kappa \mathrm{B}$ & {$[53]$} \\
\hline & $\begin{array}{l}\text { Glial cell derived neurotrophic factor } \\
\text { (GDNF) }\end{array}$ & $\alpha \mathrm{v} \beta 3$ & MEK/ERK/IKK $\alpha / \beta / \mathrm{NF}-\kappa \mathrm{B}$ & {$[54]$} \\
\hline & $\begin{array}{l}\text { Receptor activator of nuclear factor } \\
\text { kappa-B ligand (RANKL) }\end{array}$ & $\beta 1$ & RANK/MEK/ERK/IKK $\alpha / \beta / N F-\kappa \mathrm{B}$ & {$[55]$} \\
\hline \multirow{3}{*}{$\begin{array}{l}\text { Inflammatory- } \\
\text { related } \\
\text { molecules }\end{array}$} & Cyclooxygenase-2 (COX-2) & $\alpha 2 \beta 1$ & $\mathrm{EP} 1 / \mathrm{PLC} / \mathrm{PKC} \alpha / \mathrm{c}-\mathrm{Src}$ & {$[56]$} \\
\hline & Bradykinin (BK) & $\alpha 2 \beta 1$ & $\mathrm{BK}$ receptors/PLC/PKC $\delta / \mathrm{NF}-\kappa \mathrm{B}$ & {$[57]$} \\
\hline & $\begin{array}{l}\text { High mobility group box chromosomal } \\
\text { protein } 1 \text { (HMGB1) }\end{array}$ & $\alpha 5 \beta 1$ & $\begin{array}{l}\text { RAGE (receptor for advanced } \\
\text { glycation end } \\
\text { products)/PI3K/Akt/c-Jun/AP-1 }\end{array}$ & [58] \\
\hline
\end{tabular}

Certain inflammation-related molecules may also play important roles in regulating migration in human chondrosarcoma cells. Cyclooxygenase-2 (COX-2), an inducible enzyme that catalyzes the formation of prostaglandin E2 $\left(\mathrm{PGE}_{2}\right)$ during inflammation, is one such molecule. $\mathrm{PGE}_{2}$ appears to upregulate the expression of the $\alpha 2 \beta 1$ integrin via the EP1/PLC/PKCa/c-Src signaling pathways, leading to increased cell migration [57]. Bradykinin (BK) is a vasoactive peptide that mediates inflammatory responses and can also stimulate cell proliferation. BK was found to enhance chondrosarcoma cell migration by increasing $\alpha 2 \beta 1$ integrin expression, through the $\mathrm{BK}$ receptor and $\mathrm{PLC} / \mathrm{PKC} \delta / \mathrm{NF}-\kappa \mathrm{B}$ signal transduction pathways [58]. High mobility group box chromosomal protein 1 (HMGB-1) was originally identified as a nuclear protein that plays important roles in chromatin organization and transcriptional regulation. HMGB-1 has multiple functions, including the release of pro-inflammatory cytokines, cell proliferation, and cell migration. In human chondrosarcoma cells, HMGB-1 appears to promote cell migration by increasing $\alpha \mathrm{v} \beta 1$ integrin expression, through the RAGE (receptor for advanced glycation end products)/PI3 K/Akt/c-Jun/AP-1 signal transduction pathway [59] (Table 1).

\section{Integrins as Signaling Receptors Regulating Chondrosarcoma Progression}

High levels of integrin expression have been found in chondrosarcomas. Often, this is correlated with metastasis and poor prognosis. In light of this, it is noteworthy that integrins can regulate a wide range of signaling pathways critical for tumor growth and metastasis.

Increasing evidence suggests that ECM and its degradation products could play important roles in cancer progression and metastasis. Many of the underlying mechanisms are likely to involve integrin signaling. Proteomic comparison of human chondrogenic tumors revealed that the protein C-propeptides of procollagens $\mathrm{I} \alpha 1$ (PC1CP) were highly expressed in human chondrosarcomas, but not in benign enchondromas. Soluble PC1CP can induce the expression of VEGF and CXCR4 in a $\beta 1$ integrin-dependent manner, and this has been linked to chondrogenic tumor vascularization and progression [60]. On the other hand, a different extracellular matrix protein, the $\mathrm{NH}_{2}$-propeptide of type IIB procollagen (PIIBNP), was found to be capable of inducing cell death in chondrosarcoma, cervical and breast cancer cell lines, via its interaction with the integrins $\alpha \mathrm{v} \beta 3$ and $\alpha \mathrm{v} \beta 5$ [61]. Osteopontin (OPN) is an important component of the extracellular matrix in bone. The OPN protein has also been found to play a crucial role in determining the metastatic potential of various cancers. For example, OPN enhances the migration of chondrosarcoma cells by upregulating MMP-9 expression, through the $\alpha \mathrm{v} \beta 3$ integrin receptor, FAK (Focal Adhesion Kinase), MEK, ERK, and NF- $\kappa$ B-dependent signaling pathways $[62,63]$ (Table 2).

The CCN family of small secreted cysteine-rich proteins has six members (CCN1 to CCN6). The name $\mathrm{CCN}$ is derived from the first three members of the family to be discovered, namely, CYR61 (cysteine-rich angiogenic protein 61 or CCN1), connective tissue growth factor (CTGF/CCN2), and nephroblastoma overexpressed (NOV/CCN3). CCNs 
TABLE 2: Integrin as a receptor regulates signalings in human chondrosarcoma cells.

\begin{tabular}{|c|c|c|c|c|c|}
\hline Groups & Ligand & Integrin signaling & Regulation & Function & References \\
\hline \multirow{3}{*}{$\begin{array}{l}\text { Extracellular matrix } \\
\text { and its degradation } \\
\text { fragments and } \\
\text { by-products }\end{array}$} & $\mathrm{PClCP}$ & $\beta 1$ & $\begin{array}{l}\text { VEGF expression } \uparrow \\
\text { CXCR4 expression } \uparrow\end{array}$ & $\begin{array}{l}\text { Inducing chondrogenic tumor } \\
\text { vascularization and progression }\end{array}$ & {$[59]$} \\
\hline & PIIBNP & $\alpha \mathrm{v} \beta 3$ and $\alpha \mathrm{v} \beta 5$ & & Inducing cell death & {$[60]$} \\
\hline & OPN & $\alpha \mathrm{v} \beta 3 / \mathrm{FAK} / \mathrm{MEK} / \mathrm{ERK} / \mathrm{NF}-\kappa \mathrm{B}$ & MMP-9 expression $\uparrow$ & Increasing cell migration & {$[61]$} \\
\hline \multirow{5}{*}{ CCN family } & CCN1 & $\alpha \mathrm{v} \beta 3 / \mathrm{FAK}$ & MMP-13 expression $\uparrow$ & Increasing cell migration & {$[62]$} \\
\hline & $\mathrm{CCN} 2$ & $\alpha \mathrm{v} \beta 3 / \mathrm{FAK}$ & MMP-13 expression $\uparrow$ & Increasing cell migration & {$[63]$} \\
\hline & $\mathrm{CCN} 3$ & $\alpha \mathrm{v} \beta 3 / \mathrm{FAK}$ & MMP-13 expression $\uparrow$ & Increasing cell migration & {$[64]$} \\
\hline & $\mathrm{CCN} 4$ & $\begin{array}{l}\alpha 5 \beta 1 / \mathrm{FAK} / \mathrm{MEK} / \mathrm{ERK} / \mathrm{IKK} \alpha / \beta / \mathrm{NF}- \\
\kappa \mathrm{B}\end{array}$ & MMP-2 activity $\uparrow$ & Increasing cell migration & {$[65]$} \\
\hline & CCN6 & $\begin{array}{l}\alpha \mathrm{v} \beta 3 \text { and } \\
\alpha \mathrm{v} \beta 5 / \mathrm{FAK} / \mathrm{MEK} / \mathrm{ERK} / \mathrm{c}-J u n / \mathrm{AP}-1\end{array}$ & ICAM-1 expression $\uparrow$ & Increasing cell migration & {$[66]$} \\
\hline
\end{tabular}

appear to regulate numerous biological processes, such as differentiation, migration, proliferation, and cell adhesion. Notably, aberrant expression of CCNs has been identified in a broad range of tumor types. In human chondrosarcoma cells, CCN1, CCN2, and CCN3 have been found to enhance cell migration by increasing MMP-13 expression; this is mediated via the $\alpha \mathrm{v} \beta 3$ integrin receptor and FAK-dependent signaling mechanisms [64-66]. Other members of the CCN family have also been studied, including CCN4 (WISP-1) and CCN6 (WISP-3). These integrin-binding proteins appear to regulate cell migration in human chondrosarcoma cells by inducing integrin-dependent signaling. CCN4 (WISP-1) increases the activity of MMP-2, via the $\alpha \mathrm{v} \beta 1$ integrin receptor and the FAK, MEK, ERK, IKK $\alpha / \beta$, and NF- $\kappa$ B pathways, leading to enhanced migration of human chondrosarcoma cells [73]. Likewise, CCN6 (WISP-3) appears to function by increasing ICAM-1 expression through the $\alpha \mathrm{v} \beta 3$ and $\alpha \mathrm{v} \beta 5$ integrin receptor, FAK, MEK, ERK, c-Jun, and AP-1 pathways [74] (Table 2).

\section{Integrins as Therapeutic Targets in Chondrosarcomas}

Given the important roles of integrin-mediated signaling in metastasis and cancer progression, there has been increasing interest in therapeutic strategies to target these proteins. In human chondrosarcomas, increased expression of integrins, including $\alpha 2 \beta 1, \alpha \mathrm{v} \beta 1, \alpha \mathrm{v} \beta 3, \beta 1$, and $\beta 5$, is closely associated with tumor progression and metastasis. Signaling through integrin receptors, such as $\alpha \mathrm{v} \beta 1, \alpha \mathrm{v} \beta 3, \alpha \mathrm{v} \beta 5$, and $\beta 1$, may also promote cancer progression by regulating cell migration. This review discusses a selection of emerging therapeutic approaches for chondrosarcoma, together with their underlying molecular mechanisms. These include (i) integrin antagonists, (ii) inhibition of the RANK/RANKL/OPG axis, (iii) inhibition of FAK, (iv) inhibition of the IGF-I/IGF-IR axis, and (v) herbal medicines.

6.1. Integrin Antagonists. Since the discovery of the integrinbinding RGD sequence motif and its importance in mediating cell attachment, efforts have been made to develop RGDrelated small molecules as integrin antagonists. Cilengitide, a cyclic RGD pentapeptide, is the first antiangiogenic small molecule developed to target the integrins $\alpha \mathrm{v} \beta 3, \alpha \mathrm{v} \beta 5$, and $\alpha \mathrm{v} \beta 1$ [75]. This drug is currently being tested in phase III clinical trials for treatment of glioblastomas, and in phase II trials for several other tumor types [76]. Chemical modifications to the cilengitide molecule, including $\mathrm{N}$-methylation at distinct positions, can modulate its biological, structural, and pharmacokinetic properties; this could enhance selectivity, particularly for the $\alpha \mathrm{v} \beta 3$ subtype [77]. In addition, since integrin $\alpha \mathrm{v} \beta 3$ is expressed on the blood vessels that supply tumors, as well as on the tumor cells themselves, antagonists to this integrin might be particularly useful for treatment of chondrosarcoma. Another drug, ATN-161, is a non-RGDbased peptide inhibitor of $\alpha \mathrm{v} \beta 1$ that is currently in clinical trials for cancer. In patients with advanced solid tumors who were given ATN-161, prolonged stable disease was observed in up to a third of the patients [78]. In a murine model of metastatic colorectal cancer, combination therapy with ATN-161 and 5-fluorouracil was found to reduce metastasis and improve survival [79]. ATN-161 has also been shown to reduce growth and metastasis of breast cancer cells implanted in mice [80]. The above findings suggest that this $\alpha \mathrm{v} \beta 1-$ inhibiting drug holds promise for the treatment of human chondrosarcomas.

Etaracizumab (also known as vitaxin, Abegrin, or MEDI522 ), a humanized anti- $\alpha \mathrm{v} \beta 3$ antibody, was the first antiintegrin monoclonal antibody to be tested in clinical trials for cancer. In a phase I study on etaracizumab, prolonged disease stabilization was observed in a number of cancer patients with metastatic lesions, who received the drug beyond the first cycle of therapy [81]. Etaracizumab was also shown to decrease osteoclastic bone resorption by impairing osteoclast attachment, without affecting osteoclast formation and multinucleation; this could be useful for reducing metastatic bone loss in cancer patients [82]. Volociximab (M200) is a chimeric mouse-human anti- $\alpha \mathrm{v} \beta 1$ monoclonal antibody, which has shown anti-angiogenic activity in vitro and in vivo $[83,84]$. In clinical trials, volociximab was well tolerated, and there is support for its efficacy in metastatic melanoma and renal cell carcinoma [85]. Consequently, these integrin antagonists may also have therapeutic potential for chondrosarcomas, to reduce metastasis and control tumor progression. 


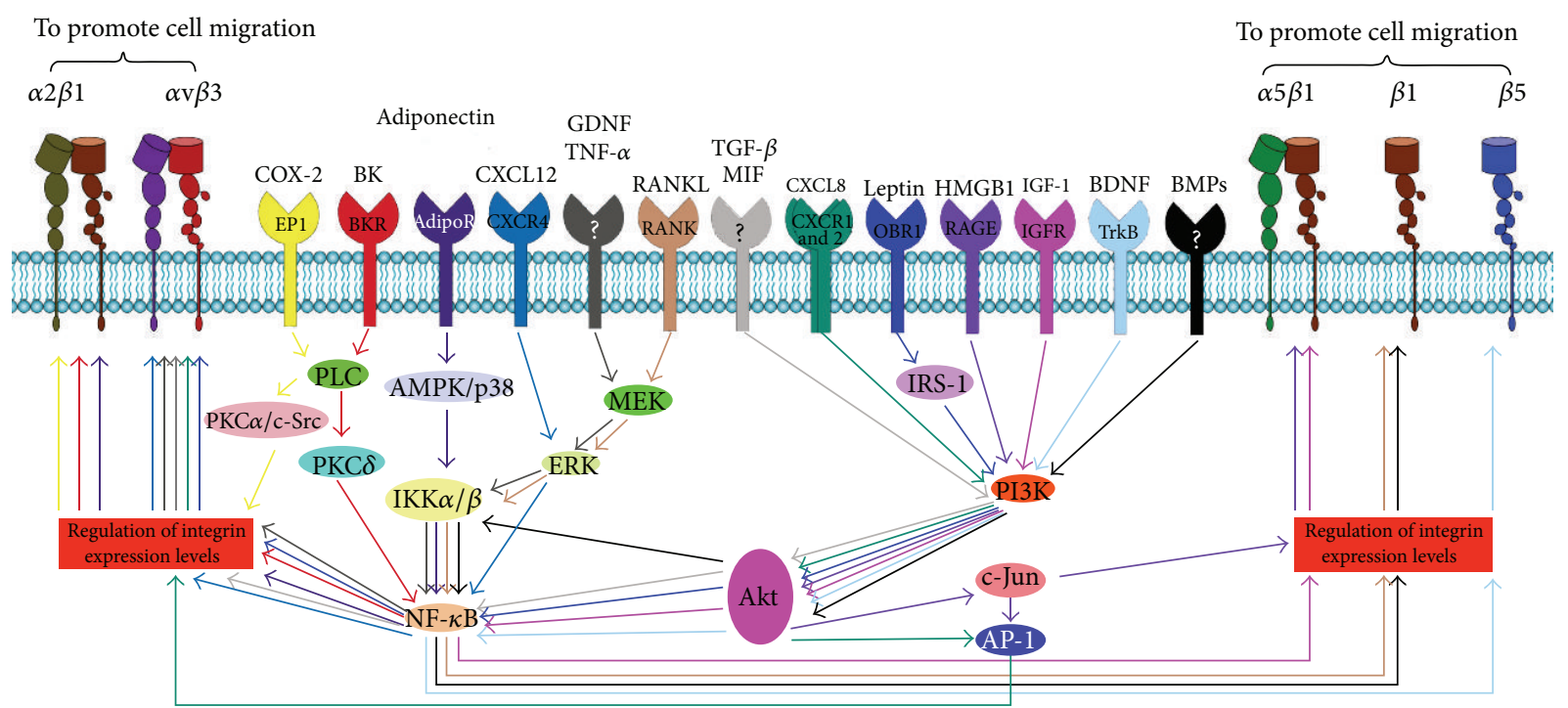

(a)

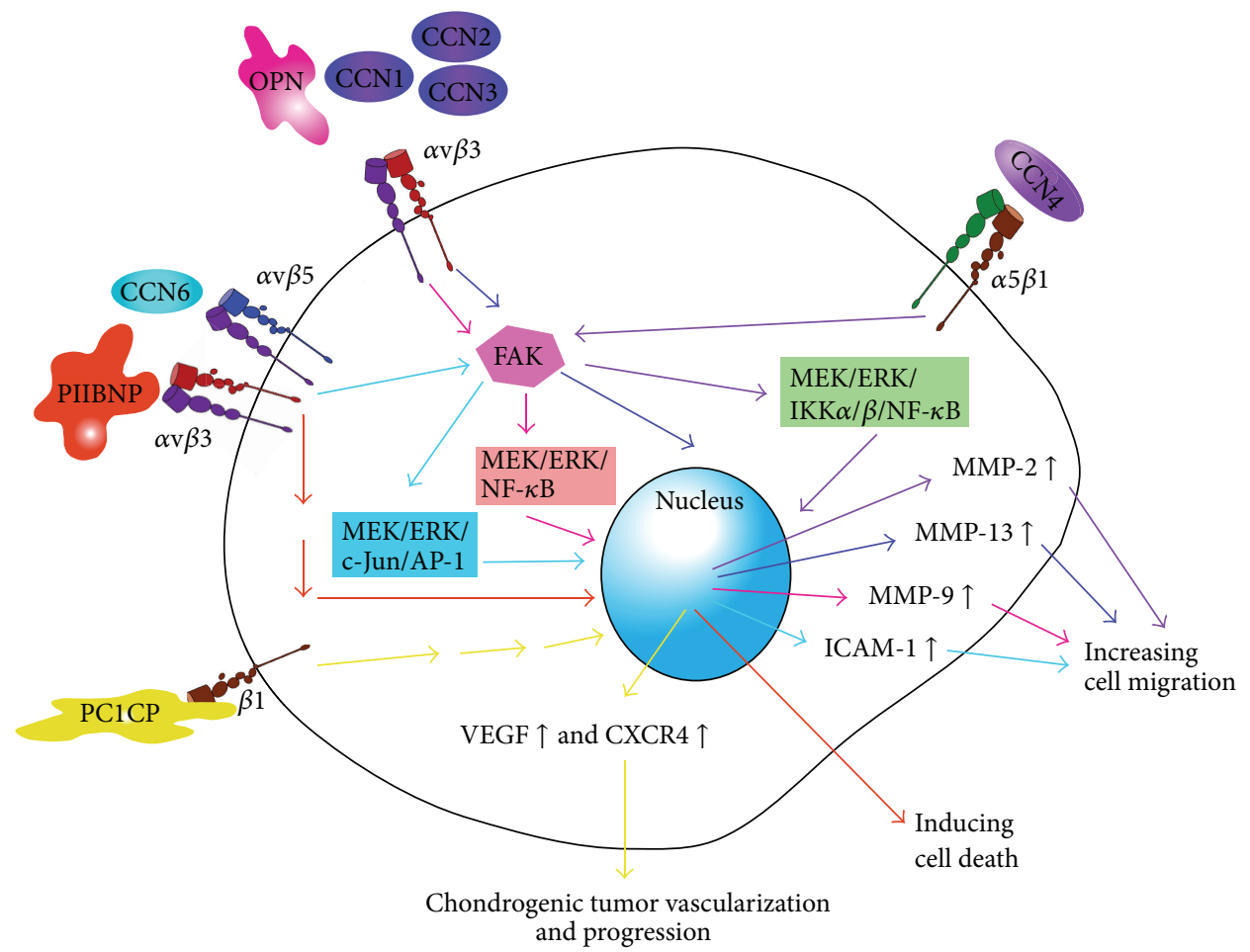

(b)

FIGURE 1: Schematic representation of the mediators that increase surface expression of integrin (a) and integrin-mediated signalings (b) which are shown to be novel therapeutic targets for chondrosarcomas.

The small molecule compound L-000845704 is an orally bioavailable nonpeptide $\alpha \mathrm{v} \beta 3$ antagonist, which has been tested in preclinical and clinical trials for the treatment of osteoporosis [86, 87]. Another orally active nonpeptide $\alpha \mathrm{v} \beta 3$ antagonist, SB 273005, has been shown to prevent and reduce edema and inflammation in a rat model of adjuvant-induced arthritis [88]. The potential applications of these integrin antagonists in the treatment of chondrosarcomas could be explored.
6.2. Inhibition of the RANK/RANKL/OPG Axis. In human chondrosarcoma tissues, RANKL and RANK expressions are higher than those in normal cartilage. Activation of the RANK/RANKL axis leads to the upregulation of $\beta 1$ integrin, and contributes to enhanced migration in human chondrosarcoma cells [56]. These observations have prompted efforts to develop therapies targeting RANKL. One promising approach involves the targeting of RANKL signaling with a decoy receptor, OPG, or with a soluble receptor form 
(RANK-Fc); this has been shown to inhibit bone metastasis in a number of murine models [89-91]. A number of clinical trials involving denosumab, a fully human monoclonal antibody against RANKL, support its use as an alternative treatment option for bone metastases [92-94].

6.3. Inhibition of FAK (Focal Adhesion Kinase). Numerous studies indicate that integrin signaling through FAK plays a role in promoting migration of chondrosarcoma cells [62, 64-66, 73, 74, 95]. Inhibition of endogenous FAK activity by adenoviral overexpression of the C-terminal domain of FAK effectively interrupts FAK signaling and its downstream events; this was found to decrease cell invasiveness in chondrosarcoma cell lines [96]. A recent phase I trial of an inhibitor of FAK showed antitumor efficacy and minimal toxicity in patients with advanced solid tumors. Such results indicate that FAK might be another promising therapeutic target [97].

6.4. Inhibition of the IGF-I/IGF-IR Axis. Insulin-like growth factor 1 (IGF-1) can enhance the migration of chondrosarcoma cells by upregulating integrin expression. In addition, integrin binding can also regulate IGF-1 receptor (IGF1R) signaling [98]. Consistent with this, blocking ligand occupancy of integrins reduced IGF-1-stimulated receptor phosphorylation, and inhibited cellular migration and DNA synthesis in response to IGF-1 [99]. This suggests that the IGF-1 signaling pathway may be another potential therapeutic target in chondrosarcoma [100]. Various IGF-1R monoclonal antibodies, including R1507, figitumumab, and ganitumab (AMG 479), have emerged as promising drugs for the treatment of Ewing's sarcoma, a small round-cell tumor that typically arises in the bones and soft tissues. A number of clinical trials to test these novel therapies are ongoing [101-105]. These drugs could potentially be explored for the treatment of other sarcomas, including chondrosarcoma.

6.5. Herbal Medicine. Berberine, an isoquinoline alkaloid, is a bioactive molecule found in the Ranunculaceae and Papaveraceae plant families. Berberine, which has been shown to inhibit cancer cell migration, was shown to downregulate $\alpha \mathrm{v} \beta 3$ integrin expression through the $\mathrm{PKC} \delta, \mathrm{c}-\mathrm{Src}$, and AP-1 pathways [106].

\section{Conclusion}

Chondrosarcomas are the second most common form of bone malignancy. These tumors are relatively resistant to chemotherapy and radiotherapy; currently, surgical resection is the only effective therapeutic option. However, 5-10\% of conventional chondrosarcomas are high-grade tumors, which show high metastatic potential and poor outcomes after resection alone. It is therefore crucial to identify and develop effective adjuvant treatments. Integrins, which are cell surface proteins involved in diverse biological processes, have been implicated in cancer cell migration, invasion, and metastasis, during tumor progression. Consequently, targeting of integrin expression and signaling has been considered a promising approach in cancer therapy. Nevertheless, integrins play a crucial role in many physiological processes; for example, tissue morphogenesis, inflammation, wound healing, and regulation of cell growth and differentiation. Any inhibition of these may cause serious adverse effects that must be taken to into account. Clinical and preclinical studies aimed at inhibiting integrin expression and signaling are ongoing. To date, however, integrin-targeted therapeutics in chondrosarcomas have not yet been successfully translated into clinical practice. This review summarizes recent progress in elucidating the molecular basis for integrin function in cancer. We have discussed various mechanisms and mediators that regulate the expression of integrins and integrin-mediated signaling (Figure 1). This understanding of molecular mechanisms could be translated into effective therapies for chondrosarcoma.

\section{Disclosure}

All authors have no financial or personal relationships with other people or organizations that could inappropriately influence their work.

\section{Acknowledgments}

This work was supported by a grant from the China Medical University (CMU102-S-26). The study sponsors were not involved in the study design, data collection, or analysis, or in the writing of the paper.

\section{References}

[1] S. E. Larsson and R. Lorentzon, "The geographic variation of the incidence of malignant primary bone tumors in Sweden," Journal of Bone and Joint Surgery A, vol. 56, no. 3, pp. 592-600, 1974.

[2] J. Bjornsson, R. A. McLeod, K. K. Unni, D. M. Ilstrup, and D. J. Pritchard, "Primary chondrosarcoma of long bones and limb girdles," Cancer, vol. 83, no. 10, pp. 2105-2119, 1998.

[3] A. Angelini, G. Guerra, A. F. Mavrogenis, E. Pala, P. Picci, and P. Ruggieri, "Clinical outcome of central conventional chondrosarcoma," Journal of Surgical Oncology, vol. 106, no. 8, pp. 929-937, 2012.

[4] F. Bertoni, P. Bacchini, and P. C. W. Hogendoorn, "Pathology and genetics. Tumours of soft tissue and bone: chondrosarcoma," in World Health Organization Classification of Tumors, pp. 247-251, IARC Press, Lyon, France, 2002.

[5] H. Gelderblom, P. C. W. Hogendoorn, S. D. Dijkstra et al., "The clinical approach towards chondrosarcoma," Oncologist, vol. 13, no. 3, pp. 320-329, 2008.

[6] H. L. Evans, A. G. Ayala, and M. M. Romsdahl, "Prognostic factors in chondrosarcoma of bone: a clinicopathologic analysis with emphasis on histologic grading," Cancer, vol. 40, no. 2, pp. 818-831, 1977.

[7] C. Y. Inwards and K. K. Unni, "Classification and grading of bone sarcomas," Hematology/Oncology Clinics of North America, vol. 9, no. 3, pp. 545-569, 1995. 
[8] G. Ayala, C. Liu, R. Nicosia, S. Horowitz, and R. Lackman, "Microvasculature and VEGF expression in cartilaginous tumors," Human Pathology, vol. 31, no. 3, pp. 341-346, 2000.

[9] H. Welkerling, S. Kratz, V. Ewerbeck, and G. Delling, "A reproducible and simple grading system for classical chondrosarcomas. Analysis of 35 chondrosarcomas and 16 enchondromas with emphasis on recurrence rate and radiological and clinical data," Virchows Archiv, vol. 443, no. 6, pp. 725-733, 2003.

[10] H. D. Dorfman and B. Czerniak, "Malignant cartilage tumors," in Bone Tumors, pp. 353-440, Mosby, Saint Louis, Mo, USA, 1998.

[11] C.-H. Tang, "Molecular mechanisms of chondrosarcoma metastasis," BioMedicine, vol. 2, no. 3, pp. 92-98, 2012.

[12] D. Donati, A. El Ghoneimy, F. Bertoni, C. Di Bella, and M. Mercuri, "Surgical treatment and outcome of conventional pelvic chondrosarcoma," Journal of Bone and Joint Surgery B, vol. 87, no. 11, pp. 1527-1530, 2005.

[13] M. Etchebehere, O. P. de Camargo, A. T. Croci, C. R. C. M. Oliveira, and A. M. Baptista, "Relationship between surgical procedure and outcome for patients with grade I chondrosarcomas," Clinics, vol. 60, no. 2, pp. 121-126, 2005.

[14] A. R. Harwood, J. I. Krajbich, and V. L. Fornasier, "Radiotherapy of chondrosarcoma of bone," Cancer, vol. 45, no. 11, pp. 2769$2777,1980$.

[15] R. Krochak, A. R. Harwood, B. J. Cummings, and I. C. Quirt, "Results of radical radiation for chondrosarcoma of bone," Radiotherapy and Oncology, vol. 1, no. 2, pp. 109-115, 1983.

[16] F. Y. Lee, H. J. Mankin, G. Fondren et al., "Chondrosarcoma of bone: an assessment of outcome," Journal of Bone and Joint Surgery A, vol. 81, no. 3, pp. 326-338, 1999.

[17] J. V. M. G. Bovée, A.-M. Cleton-Jansen, A. H. M. Taminiau, and P. C. W. Hogendoorn, "Emerging pathways in the development of chondrosarcoma of bone and implications for targeted treatment," The Lancet Oncology, vol. 6, no. 8, pp. 599-607, 2005.

[18] R. M. Terek, G. K. Schwartz, K. Devaney et al., "Chemotherapy and P-glycoprotein expression in chondrosarcoma," Journal of Orthopaedic Research, vol. 16, no. 5, pp. 585-590, 1998.

[19] J. J. Wyman, A. M. Hornstein, P. A. Meitner et al., "Multidrug resistance-1 and p-glycoprotein in human chondrosarcoma cell lines: expression correlates with decreased intracellular doxorubicin and in vitro chemoresistance," Journal of Orthopaedic Research, vol. 17, no. 6, pp. 935-940, 1999.

[20] R. Rathinam and S. K. Alahari, "Important role of integrins in the cancer biology," Cancer and Metastasis Reviews, vol. 29, no. 1, pp. 223-237, 2010.

[21] R. O. Hynes, "Integrins: bidirectional, allosteric signaling machines," Cell, vol. 110, no. 6, pp. 673-687, 2002.

[22] M. Barczyk, S. Carracedo, and D. Gullberg, "Integrins," Cell and Tissue Research, vol. 339, no. 1, pp. 269-280, 2010.

[23] S. L. Goodman and M. Picard, "Integrins as therapeutic targets," Trends in Pharmacological Sciences, vol. 33, no. 7, pp. 405-412, 2012.

[24] O. Vinogradova, A. Velyvis, A. Velyviene et al., "A structural mechanism of integrin $\alpha \operatorname{IIb} \beta 3$ "inside-out" activation as regulated by its cytoplasmic face," Cell, vol. 110, no. 5, pp. 587-597, 2002.

[25] K. R. Legate and R. Fässler, "Mechanisms that regulate adaptor binding to $\beta$-integrin cytoplasmic tails," Journal of Cell Science, vol. 122, no. 2, pp. 187-198, 2009.

[26] J. A. Askari, P. A. Buckley, A. P. Mould, and M. J. Humphries, "Linking integrin conformation to function," Journal of Cell Science, vol. 122, no. 2, pp. 165-170, 2009.
[27] A. W. Partridge, S. Liu, S. Kim, J. U. Bowie, and M. H. Ginsberg, "Transmembrane domain helix packing stabilizes integrin $\alpha \operatorname{IIb} \beta 3$ in the low affinity state," The Journal of Biological Chemistry, vol. 280, no. 8, pp. 7294-7300, 2005.

[28] M. Moser, K. R. Legate, R. Zent, and R. Fässler, "The tail of integrins, talin, and kindlins," Science, vol. 324, no. 5929, pp. 895-899, 2009.

[29] S. J. Shattil, C. Kim, and M. H. Ginsberg, "The final steps of integrin activation: the end game," Nature Reviews Molecular Cell Biology, vol. 11, no. 4, pp. 288-300, 2010.

[30] W. Guo, Y. Pylayeva, A. Pepe et al., “ $\beta 4$ integrin amplifies ErbB2 signaling to promote mammary tumorigenesis," Cell, vol. 126, no. 3, pp. 489-502, 2006.

[31] I. Macias-Perez, C. Borza, X. Chen et al., "Loss of integrin $\alpha 1 \beta 1$ ameliorates kras-induced lung cancer," Cancer Research, vol. 68, no. 15 , pp. 6127-6135, 2008.

[32] S. Huveneers, I. van den Bout, P. Sonneveld, A. Sancho, A. Sonnenberg, and E. H. J. Danen, "Integrin $\alpha \mathrm{v} \beta 3$ controls activity and oncogenic potential of primed c-Src," Cancer Research, vol. 67, no. 6, pp. 2693-2700, 2007.

[33] J. S. Desgrosellier, L. A. Barnes, D. J. Shields et al., "An integrin $\alpha$ v B 3-c-Src oncogenic unit promotes anchorage-independence and tumor progression," Nature Medicine, vol. 15, no. 10, pp. 1163-1169, 2009.

[34] L. Huck, S. M. Pontier, D. M. Zuo, and W. J. Muller, " $\beta 1$ integrin is dispensable for the induction of ErbB2 mammary tumors but plays a critical role in the metastatic phase of tumor progression," Proceedings of the National Academy of Sciences of the United States of America, vol. 107, no. 35, pp. 15559-15564, 2010.

[35] S. Miyamoto, H. Teramoto, J. S. Gutkind, and K. M. Yamada, "Integrins can collaborate with growth factors for phosphorylation of receptor tyrosine kinases and MAP kinase activation: roles of integrin aggregation and occupancy of receptors," Journal of Cell Biology, vol. 135, no. 6, pp. 1633-1642, 1996.

[36] L. Moro, M. Venturino, C. Bozzo et al., "Integrins induce activation of EGF receptor: role in MAP kinase induction and adhesion-dependent cell survival," EMBO Journal, vol. 17, no. 22, pp. 6622-6632, 1998.

[37] Y. Ning, R. Zeineldin, Y. Liu, M. Rosenberg, M. S. Stack, and L. G. Hudson, "Down-regulation of integrin $\alpha 2$ surface expression by mutant epidermal growth factor receptor (EGFRvIII) induces aberrant cell spreading and focal adhesion formation," Cancer Research, vol. 65, no. 20, pp. 9280-9286, 2005.

[38] S. De, O. Razorenova, N. P. McCabe, T. O’Toole, J. Qin, and T. V. Byzova, "VEGF-integrin interplay controls tumor growth and vascularization," Proceedings of the National Academy of Sciences of the United States of America, vol. 102, no. 21, pp. 7589-7594, 2005.

[39] G. H. Mahabeleshwar, W. Feng, K. Reddy, E. F. Plow, and T. V. Byzova, "Mechanisms of integrin-vascular endothelial growth factor receptor cross-activation in angiogenesis," Circulation Research, vol. 101, no. 6, pp. 570-580, 2007.

[40] T. Engl, B. Relja, D. Marian et al., "CXCR4 chemokine receptor mediates prostate tumor cell adhesion through $\alpha 5$ and $\beta 3$ integrins," Neoplasia, vol. 8, no. 4, pp. 290-301, 2006.

[41] T. N. Hartmann, J. A. Burger, A. Glodek, N. Fujii, and M. Burger, "CXCR4 chemokine receptor and integrin signaling co-operate in mediating adhesion and chemoresistance in small cell lung cancer (SCLC) cells," Oncogene, vol. 24, no. 27, pp. 4462-4471, 2005. 
[42] J. J. Grzesiak, K. C. Smith, D. W. Burton, L. J. Deftos, and M. Bouvet, "Integrin-mediated laminin-1 adhesion upregulates CXCR4 and IL-8 expression in pancreatic cancer cells," Surgery, vol. 141, no. 6, pp. 804-814, 2007.

[43] K. M. Yamada and S. Even-Ram, "Integrin regulation of growth factor receptors," Nature Cell Biology, vol. 4, no. 4, pp. E75-E76, 2002.

[44] G. Giannelli, E. Fransvea, F. Marinosci et al., "Transforming growth factor- $\beta 1$ triggers hepatocellular carcinoma invasiveness via $\alpha 3 \beta 1$ integrin," American Journal of Pathology, vol. 161, no. 1 , pp. 183-193, 2002.

[45] C.-M. Wu, T.-M. Li, S.-F. Hsu et al., "IGF-I enhances $\alpha 5 \beta 1$ integrin expression and cell motility in human chondrosarcoma cells," Journal of Cellular Physiology, vol. 226, no. 12, pp. 32703277, 2011.

[46] C. Y. Lin, H. J. Chen, T. M. Li et al., "beta5 integrin up-regulation in brain-derived neurotrophic factor promotes cell motility in human chondrosarcoma," PLoS ONE, vol. 8, no. 7, Article ID e67990, 2013.

[47] C.-Y. Lee, C.-Y. Huang, M.-Y. Chen, C.-Y. Lin, H.-C. Hsu, and C.-H. Tang, "IL-8 increases integrin expression and cell motility in human chondrosarcoma cells," Journal of Cellular Biochemistry, vol. 112, no. 9, pp. 2549-2557, 2011.

[48] T.-H. Lai, Y.-C. Fong, W.-M. Fu, R.-S. Yang, and C.-H. Tang, "Stromal cell-derived factor- 1 increase $\alpha \mathrm{v} \beta 3$ integrin expression and invasion in human chondrosarcoma cells," Journal of Cellular Physiology, vol. 218, no. 2, pp. 334-342, 2009.

[49] C.-H. Hou, R.-S. Yang, S.-M. Hou, and C.-H. Tang, “TNF- $\alpha$ increases $\alpha \mathrm{v} \beta 3$ integrin expression and migration in human chondrosarcoma cells," Journal of Cellular Physiology, vol. 226, no. 3, pp. 792-799, 2011.

[50] S.-N. Yang, H.-T. Chen, H.-K. Tsou et al., "Leptin enhances cell migration in human chondrosarcoma cells through OBRl leptin receptor," Carcinogenesis, vol. 30, no. 4, pp. 566-574, 2009.

[51] Y.-C. Chiu, D.-C. Shieh, K.-M. Tong et al., "Involvement of AdipoR receptor in adiponectin-induced motility and $\alpha 2 \beta 1$ integrin upregulation in human chondrosarcoma cells," Carcinogenesis, vol. 30, no. 10, pp. 1651-1659, 2009.

[52] C.-Y. Lee, M.-J. Su, C.-Y. Huang et al., "Macrophage migration inhibitory factor increases cell motility and up-regulates $\alpha \mathrm{v} \beta 3$ integrin in human chondrosarcoma cells," Journal of Cellular Biochemistry, vol. 113, no. 5, pp. 1590-1598, 2012.

[53] Y.-Y. Yeh, C.-C. Chiao, W.-Y. Kuo et al., “TGF- $\beta 1$ increases motility and $\alpha \mathrm{v} \beta 3$ integrin up-regulation via PI3K, Akt and NF- $\kappa \mathrm{B}$-dependent pathway in human chondrosarcoma cells," Biochemical Pharmacology, vol. 75, no. 6, pp. 1292-1301, 2008.

[54] Y.-C. Fong, T.-M. Li, C.-M. Wu et al., "BMP-2 increases migration of human chondrosarcoma cells via PI3K/Akt pathway," Journal of Cellular Physiology, vol. 217, no. 3, pp. 846-855, 2008.

[55] C.-M. Su, D.-Y. Lu, C.-J. Hsu et al., "Glial cell-derived neurotrophic factor increases migration of human chondrosarcoma cells via ERK and NF- $\kappa$ B pathways," Journal of Cellular Physiology, vol. 220, no. 2, pp. 499-507, 2009.

[56] C.-J. Hsu, T.-Y. Lin, C.-C. Kuo et al., "Involvement of integrin up-regulation in RANKL/RANK pathway of chondrosarcomas migration," Journal of Cellular Biochemistry, vol. 111, no. 1, pp. 138-147, 2010.

[57] J.-F. Liu, Y.-C. Fong, C.-S. Chang et al., "Cyclooxygenase-2 enhances $\alpha 2 \beta 1$ integrin expression and cell migration via EP1 dependent signaling pathway in human chondrosarcoma cells," Molecular Cancer, vol. 9, article 43, 2010.
[58] W.-H. Yang, J.-T. Chang, S.-F. Hsu et al., "Bradykinin enhances cell migration in human chondrosarcoma cells through BK receptor signaling pathways," Journal of Cellular Biochemistry, vol. 109, no. 1, pp. 82-92, 2010.

[59] C.-H. Tang, Y.-T. Keng, and J.-F. Liu, "HMGB-1 induces cell motility and $\alpha 5 \beta 1$ integrin expression in human chondrosarcoma cells," Cancer Letters, vol. 322, no. 1, pp. 98-106, 2012.

[60] J.-B. Vincourt, S. Etienne, J. Cottet et al., "C-propeptides of procollagens $\mathrm{I} \alpha 1$ and II that differentially accumulate in enchondromas versus chondrosarcomas regulate tumor cell survival and migration," Cancer Research, vol. 70, no. 11, pp. 4739-4748, 2010.

[61] Z. Wang, J. Bryan, C. Franz, N. Havlioglu, and L. J. Sandell, "Type IIB procollagen NH2-propeptide induces death of tumor cells via interaction with integrins $\alpha \mathrm{v} \beta 3$ and $\alpha \mathrm{v} \beta 5$," The Journal of Biological Chemistry, vol. 285, no. 27, pp. 20806-20817, 2010.

[62] Y.-J. Chen, Y.-Y. Wei, H.-T. Chen et al., "Osteopontin increases migration and MMP-9 up-regulation via $\alpha \mathrm{v} \beta 3$ integrin, FAK, ERK, and NF- $\kappa$ B-dependent pathway in human chondrosarcoma cells," Journal of Cellular Physiology, vol. 221, no. 1, pp. 98108, 2009.

[63] S. C. Hsu, J. H. Lin, S. W. Weng et al., "Crude extract of Rheum palmatum inhibits migration and invasion of U-2 OS human osteosarcoma cells by suppression of matrix metalloproteinase2 and -9," BioMedicine, vol. 3, no. 3, pp. 120-129, 2013.

[64] T.-W. Tan, W.-H. Yang, Y.-T. Lin et al., "Cyr61 increases migration and MMP- 13 expression via $\alpha \mathrm{v} \beta 3$ integrin, FAK, ERK and AP-1-dependent pathway in human chondrosarcoma cells," Carcinogenesis, vol. 30, no. 2, pp. 258-268, 2009.

[65] T.-W. Tan, C.-H. Lai, C.-Y. Huang et al., "CTGF enhances migration and MMP-13 up-regulation via $\alpha \mathrm{v} \beta 3$ integrin, FAK, ERK, and NF- $\kappa$ B-dependent pathway in human chondrosarcoma cells," Journal of Cellular Biochemistry, vol. 107, no. 2, pp. 345-356, 2009.

[66] H.-E. Tzeng, J.-C. Chen, C.-H. Tsai et al., "CCN3 increases cell motility and MMP-13 expression in human chondrosarcoma through integrin-dependent pathway," Journal of Cellular Physiology, vol. 226, no. 12, pp. 3181-3189, 2011.

[67] H.-P. Kim, M.-S. Lee, J. Yu et al., “TGF- $\beta 1$ (transforming growth factor- $\beta 1$ )-mediated adhesion of gastric carcinoma cells involves a decrease in Ras/ERKs (extracellular-signal- regulated kinases) cascade activity dependent on c-Src activity," Biochemical Journal, vol. 379, no. 1, pp. 141-150, 2004.

[68] T. Narita, N. Kawakami-Kimura, M. Sato et al., "Alteration of integrins by heparin-binding EGF-like growth factor in human breast cancer cells," Oncology, vol. 53, no. 5, pp. 374-381, 1996.

[69] B. Xue, W. Wu, K. Huang et al., "Stromal cell-derived factor1 (SDF-1) enhances cells invasion by alphavbeta6 integrinmediated signaling in ovarian cancer," Molecular and Cellular Biochemistry, vol. 380, no. 1-2, pp. 177-184, 2013.

[70] S.-W. Wang, H.-H. Wu, S.-C. Liu et al., "CCL5 and CCR5 interaction promotes cell motility in human osteosarcoma," PLoS ONE, vol. 7, no. 4, Article ID e35101, 2012.

[71] H. Sawai, H. Funahashi, M. Yamamoto et al., "Interleukin-1 $\alpha$ enhances integrin $\alpha 6 \beta 1$ expression and metastatic capability of human pancreatic cancer," Oncology, vol. 65, no. 2, pp. 167-173, 2003.

[72] H. Sawai, Y. Okada, H. Funahashi et al., "Interleukin- $1 \alpha$ enhances the aggressive behavior of pancreatic cancer cells by regulating the $\alpha 6 \beta 1$-integrin and urokinase plasminogen activator receptor expression," BMC Cell Biology, vol. 7, article 8, 2006. 
[73] C.-H. Hou, Y.-C. Chiang, Y.-C. Fong, and C.-H. Tang, "WISP1 increases MMP-2 expression and cell motility in human chondrosarcoma cells," Biochemical Pharmacology, vol. 81, no. 11, pp. 1286-1295, 2011.

[74] Y.-C. Fong, C.-Y. Lin, Y.-C. Su et al., "CCN6 enhances ICAM-1 expression and cell motility in human chondrosarcoma cells," Journal of Cellular Physiology, vol. 227, no. 1, pp. 223-232, 2012.

[75] C. Mas-Moruno, F. Rechenmacher, and H. Kessler, "Cilengitide: the first anti-angiogenic small molecule drug candidate. Design, synthesis andclinical evaluation," Anti-Cancer Agents in Medicinal Chemistry, vol. 10, no. 10, pp. 753-768, 2010.

[76] J. S. Desgrosellier and D. A. Cheresh, "Integrins in cancer: biological implications and therapeutic opportunities," Nature Reviews Cancer, vol. 10, no. 1, pp. 9-22, 2010.

[77] C. Mas-Moruno, J. G. Beck, L. Doedens et al., "Increasing $\alpha v \beta 3$ selectivity of the anti-angiogenic drug cilengitide by $\mathrm{N}-$ methylation," Angewandte Chemie, vol. 50, no. 40, pp. 94969500, 2011.

[78] M. E. Cianfrocca, K. A. Kimmel, J. Gallo et al., "Phase 1 trial of the antiangiogenic peptide ATN-161 (Ac-PHSCN-NH2), a beta integrin antagonist, in patients with solid tumours," British Journal of Cancer, vol. 94, no. 11, pp. 1621-1626, 2006.

[79] O. Stoeltzing, W. Liu, N. Reinmuth et al., "Inhibition of integrin $\alpha 5 \beta 1$ function with a small peptide (ATN-161) plus continuous 5 -fu infusion reduces colorectal liver metastases and improves survival in mice," International Journal of Cancer, vol. 104, no. 4, pp. 496-503, 2003.

[80] P. Khalili, A. Arakelian, G. Chen et al., "A non-RGD-based integrin binding peptide (ATN-161) blocks breast cancer growth and metastasis in vivo," Molecular Cancer Therapeutics, vol. 5, no. 9, pp. 2271-2280, 2006.

[81] J. C. Gutheil, T. N. Campbell, P. R. Pierce et al., "Targeted antiangiogenic therapy for cancer using vitaxin: a humanized monoclonal antibody to the integrin $\alpha(\mathrm{v}) \beta 3$," Clinical Cancer Research, vol. 6, no. 8, pp. 3056-3061, 2000.

[82] A. Gramoun, S. Shorey, J. D. Bashutski et al., "Effects of Vitaxin, a novel therapeutic in trial for metastatic bone tumors, on osteoclast functions in vitro," Journal of Cellular Biochemistry, vol. 102, no. 2, pp. 341-352, 2007.

[83] V. Ramakrishnan, V. Bhaskar, D. A. Law et al., "Preclinical evaluation of an anti- $\alpha 5 \beta 1$ integrin antibody as a novel antiangiogenic agent," Journal of Experimental Therapeutics and Oncology, vol. 5, no. 4, pp. 273-286, 2006.

[84] V. Bhaskar, D. Zhang, M. Fox et al., "A function blocking anti-mouse integrin $\alpha 5 \beta 1$ antibody inhibits angiogenesis and impedes tumor growth in vivo," Journal of Translational Medicine, vol. 5, article 61, 2007.

[85] A. D. Ricart, A. W. Tolcher, G. Liu et al., "Volociximab, a chimeric monoclonal antibody that specifically binds $\alpha 5 \beta 1$ integrin: a phase l, pharmacokinetic, and biological correlative study," Clinical Cancer Research, vol. 14, no. 23, pp. 7924-7929, 2008.

[86] J. H. Hutchinson, W. Halczenko, K. M. Brashear et al., "Nonpeptide $\alpha \mathrm{v} \beta 3$ antagonists. 8. In vitro and in vivo evaluation of a potent $\alpha \mathrm{v} \beta 3$ antagonist for the prevention and treatment of osteoporosis," Journal of Medicinal Chemistry, vol. 46, no. 22, pp. 4790-4798, 2003.

[87] M. G. Murphy, K. Cerchio, S. A. Stoch, K. Gottesdiener, M. $\mathrm{Wu}$, and R. Recker, "Effect of L-000845704, an $\alpha \mathrm{V} \beta 3$ integrin antagonist, on markers of bone turnover and bone mineral density in postmenopausal osteoporotic women," Journal of
Clinical Endocrinology and Metabolism, vol. 90, no. 4, pp. 20222028, 2005.

[88] A. M. Badger, S. Blake, R. Kapadia et al., "Disease-modifying activity of SB, 273005, an orally active, nonpeptide alphavbeta3 (vitronectin receptor) antagonist, in rat adjuvant-induced arthritis," Arthritis \& Rheumatism, vol. 44, no. 1, pp. 128-137, 2001.

[89] F. Lamoureux, P. Richard, Y. Wittrant et al., "Therapeutic relevance of osteoprotegerin gene therapy in osteosarcoma: blockade of the vicious cycle between tumor cell proliferation and bone resorption," Cancer Research, vol. 67, no. 15, pp. 73087318, 2007.

[90] F. Lamoureux, G. Picarda, J. Rousseau et al., "Therapeutic efficacy of soluble receptor activator of nuclear factor- $\kappa \mathrm{B}$ Fc delivered by nonviral gene transfer in a mouse model of osteolytic osteosarcoma," Molecular Cancer Therapeutics, vol. 7, no. 10, pp. 3389-3398, 2008.

[91] J. Rousseau, V. Escriou, F. Lamoureux et al., "Formulated siRNAs targeting Rankl prevent osteolysis and enhance chemotherapeutic response in osteosarcoma models," Journal of Bone and Mineral Research, vol. 26, no. 10, pp. 2452-2462, 2011.

[92] D. H. Henry, L. Costa, F. Goldwasser et al., "Randomized, double-blind study of denosumab versus zoledronic acid in the treatment of bone metastases in patients with advanced cancer (excluding breast and prostate cancer) or multiple myeloma," Journal of Clinical Oncology, vol. 29, no. 9, pp. 1125-1132, 2011.

[93] K. Fizazi, M. Carducci, M. Smith et al., "Denosumab versus zoledronic acid for treatment of bone metastases in men with castration-resistant prostate cancer: a randomised, doubleblind study," The Lancet, vol. 377, no. 9768, pp. 813-822, 2011.

[94] M. R. Smith, F. Saad, R. Coleman et al., "Denosumab and bone-metastasis-free survival in men with castration-resistant prostate cancer: results of a phase 3, randomised, placebocontrolled trial," The Lancet, vol. 379, no. 9810, pp. 39-46, 2012.

[95] M.-C. Maa and T.-H. Leu, "Activation of Toll-like receptors induces macrophage migration via the iNOS/Src/FAK pathway," BioMedicine, vol. 1, no. 1, pp. 11-15, 2011.

[96] J. W. Lee, Y. H. Kim, H. B. Park et al., “The C-terminal domain of focal adhesion kinase reduces the tumor cell invasiveness in chondrosarcoma cell lines," Journal of Orthopaedic Research, vol. 21, no. 6, pp. 1071-1080, 2003.

[97] J. R. Infante, D. R. Camidge, L. R. Mileshkin et al., "Safety, pharmacokinetic, and pharmacodynamic phase I dose-escalation trial of PF-00562271, an inhibitor of focal adhesion kinase, in advanced solid tumors," Journal of Clinical Oncology, vol. 30, no. 13, pp. 1527-1533, 2012.

[98] D. R. Clemmons and L. A. Maile, "Minireview: integral membrane proteins that function coordinately with the insulin-like growth factor I receptor to regulate intracellular signaling," Endocrinology, vol. 144, no. 5, pp. 1664-1670, 2003.

[99] L. A. Maile and D. R. Clemmons, “The $\alpha \mathrm{V} \beta 3$ integrin regulates insulin-like growth factor I (IGF-I) receptor phosphorylation by altering the rate of recruitment of the Src-homology 2containing phosphotyrosine phosphatase- 2 to the activated IGF-I receptor," Endocrinology, vol. 143, no. 11, pp. 4259-4264, 2002.

[100] J. A. Toretsky and R. Gorlick, "IGF-1R targeted treatment of sarcoma," The Lancet Oncology, vol. 11, no. 2, pp. 105-106, 2010.

[101] E. D. Fleuren, Y. M. Versleijen-Jonkers, S. Heskamp et al., "The strength of small: improved targeting of Insulin-like Growth 
Factor-1 Receptor (IGF-1R) with F(ab')(2)-R1507 fragments in Ewing sarcomas," Journal of Cancer, vol. 49, no. 13, pp. 28512858, 2013.

[102] I. Asmane, E. Watkin, L. Alberti et al., "Insulin-like growth factor type 1 receptor (IGF-1R) exclusive nuclear staining: a predictive biomarker for IGF-1R monoclonal antibody (Ab) therapy in sarcomas," European Journal of Cancer, vol. 48, no. 16, pp. 3027-3035, 2012.

[103] W. D. Tap, G. Demetri, P. Barnette et al., "Phase II study of ganitumab, a fully human anti-type-1 insulin-like growth factor receptor antibody, in patients with metastatic Ewing family tumors or desmoplastic small round cell tumors," Journal of Clinical Oncology, vol. 30, no. 15, pp. 1849-1856, 2012.

[104] A. S. Pappo, S. R. Patel, J. Crowley et al., "R1507, a monoclonal antibody to the insulin-like growth factor 1 receptor, in patients with recurrent or refractory Ewing sarcoma family of tumors: Results of a phase II Sarcoma Alliance for research through Collaboration study," Journal of Clinical Oncology, vol. 29, no. 34, pp. 4541-4547, 2011.

[105] H. Juergens, N. C. Daw, B. Geoerger et al., "Preliminary efficacy of the anti-insulin-like growth factor type 1 receptor antibody figitumumab in patients with refractory Ewing sarcoma," Journal of Clinical Oncology, vol. 29, no. 34, pp. 4534-4540, 2011.

[106] C. M. Wu, T. M. Li, T. W. Tan, Y. C. Fong, and C. H. Tang, "Berberine reduces the metastasis of chondrosarcoma by modulating the $\alpha \mathrm{v} \beta 3$ integrin and the $\mathrm{PKC} \delta, \mathrm{c}-\mathrm{Src}$, and AP-1 signaling pathways " Evidence-based Complementary and Alternative Medicine, vol. 2013, Article ID 423164, 10 pages, 2013. 

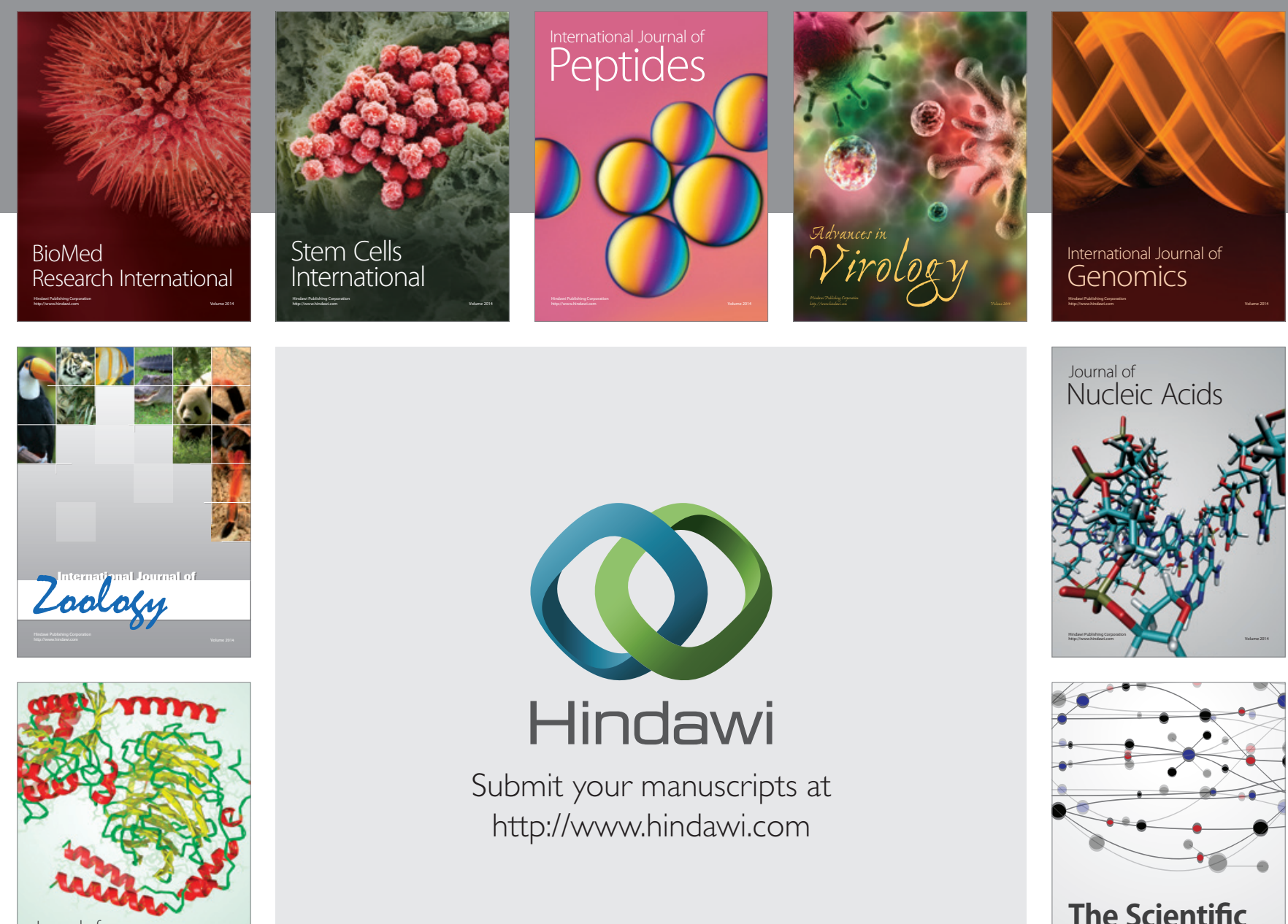

Submit your manuscripts at

http://www.hindawi.com

Journal of
Signal Transduction
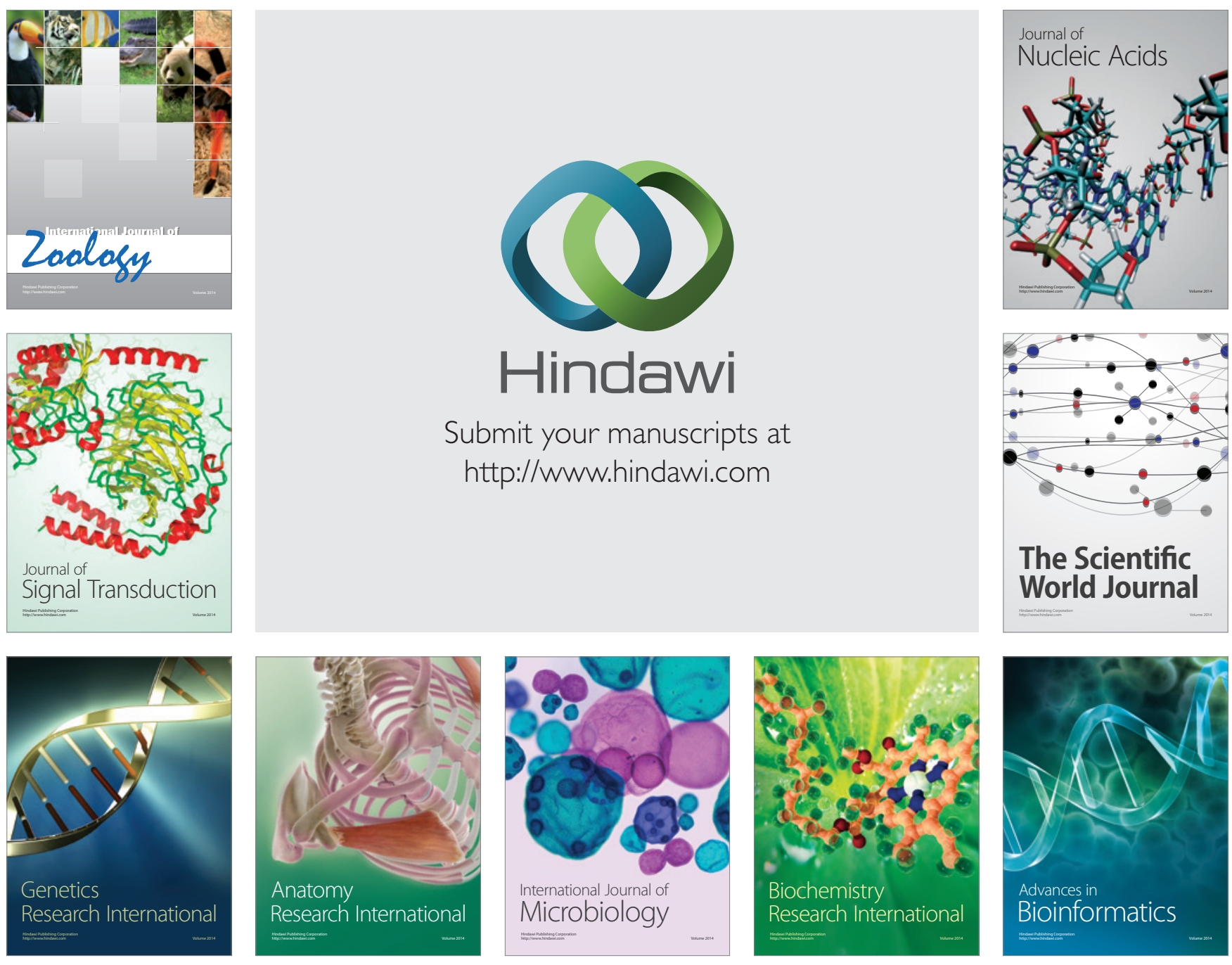

The Scientific World Journal
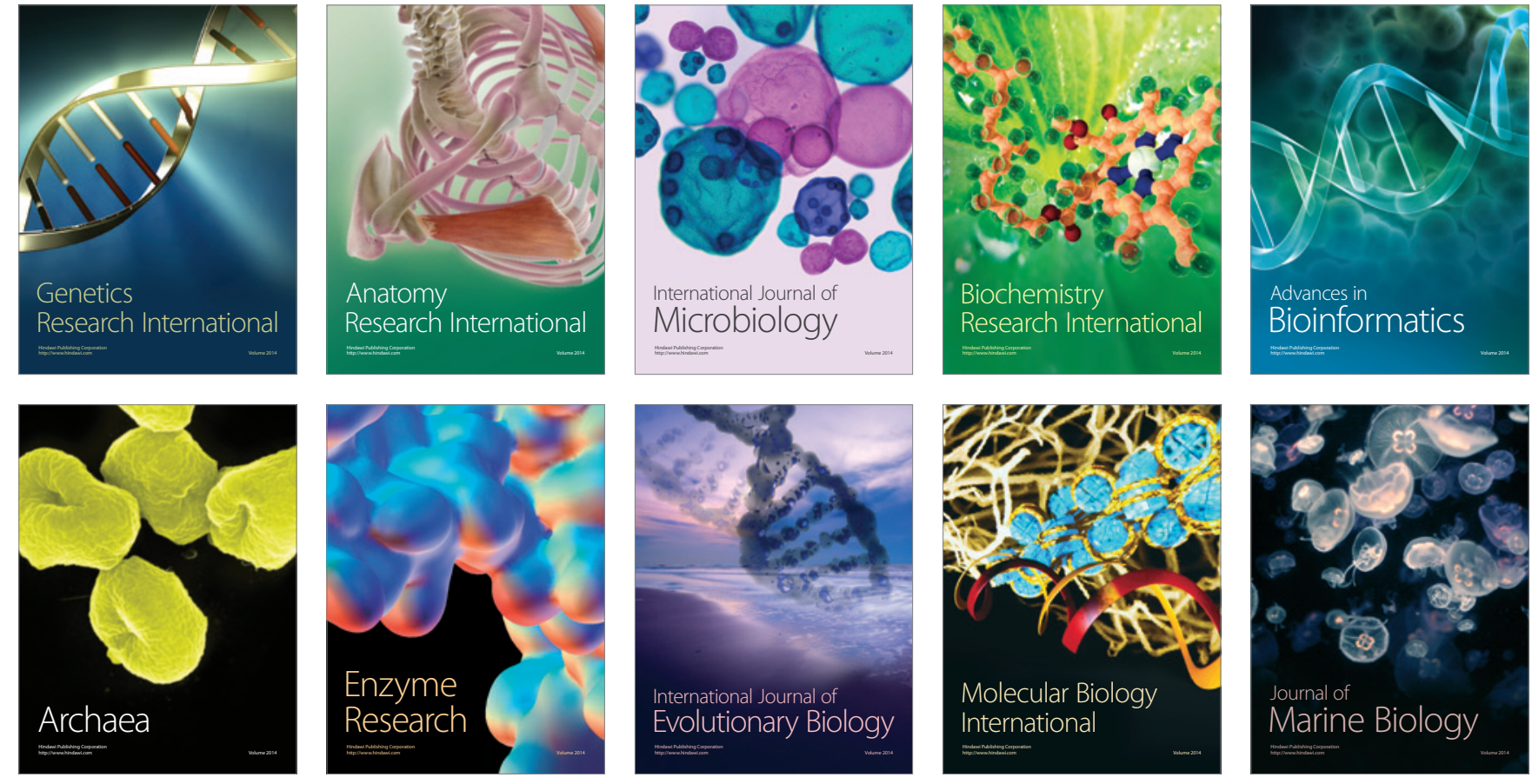